\title{
PELATIHAN PENGEMBANGAN PERANGKAT PEMBELAJARAN FISIKA BERBASIS KETERAMPILAN PROSES DI SMP MUHAMMADIYAH 2 DEPOK SLEMAN
}

\author{
Oleh: \\ Widodo, Laifa Rahmawati, Toni Kus Indratno, Ariati Dina P \\ Program Studi Pendidikan Fisika, Fakultas Keguruan dan Ilmu Pendidikan \\ Universitas Ahmad Dahlan Yogyakarta
}

\section{Ringkasan}

Keterampilan proses sains merupakan salah satu keterampilan yang menjadi panduan bagi siswa untuk belajar sains secara holistic. Pelaksanaan keterampilan proses sains dalam pembelajaran membutuhkan pemahaman terhadap karakteristik, langkah-langkah pelaksanaan, serta pembuatan perangkat pembelajaran. Banyak guru IPA SMP Muhammadiyah Kabupaten Sleman yang mengalami kendala dalam melaksanakan pembelajaran yang berbasiskan pada keterampilan proses sains. Pelatihan ini dilakukan untuk membekali guru IPA SMP Muhammadiyah Kabupaten Sleman bagian timur untuk dengan pemahaman tentang pengambangan perangkat pembelajaran berbasis keterampilan proses sains.

Pelatihan dilakukan selama dua hari, yaitu pada tgl. 28-29 Agustus 2017 di SMP Muhammadiyah 2 Depok Sleman. Pelatuhan dilakukan dalam dua sesi materi. Sesi materi pertama tentang materi keterampilan proses sains. Sesi materi kedua tentang penyusunan langkah kerja eksperimen menggunakan kit IPA rangkaian listrik. Peserta berasal dari 9 SMP Muhammadiyah. Berdasarkan evaluasi yang dilakukan setelah kegiatan, bahwa peserta merasa perlu untuk dilakukan kegiatan serupa terutama untuk eksperimen terkait kit IPA lainnya.

Kata Kunci: pelatihan, perangkat pembelajaran, fisika, keterampilan proses sains.

\begin{abstract}
Scientific process skills are one of the skills that guide students to learn science holistically. Implementation of science process skills in learning requires an understanding of the characteristics, implementation steps, and the making of learning tools. Many science teachers of SMP Muhammadiyah of Sleman District experience obstacles in implementing learning based on science process skills. The training was conducted to equip the science teachers of SMP Muhammadiyah in East Sleman district to understand the mining of science-based learning process tools.

The training was conducted for two days, ie on date. 28-29 August 2017 at SMP Muhammadiyah 2 Depok Sleman. The compliance took place in two material sessions. The first session of material is about science process skill material. The second material session on the preparation of experimental work steps using IPA circuit kits. Participants come from 9 SMP Muhammadiyah. Based on the evaluation conducted after the activity, the participants felt the need to do similar activities especially for experiments related to other science kits.
\end{abstract}

Keywords: Training, Learning Tools, Physics, Science Process Skills

\section{A. PENDAhuluan}

\section{Latar Belakang}

Keterampilan proses sains merupakan salah satu keterampilan yang menjadi panduan bagi siswa untuk belajar sains secara holistic. Pelaksanaan keterampilan proses sains dalam pembelajaran membutuhkan pemahaman terhadap karakteristik, langkahlangkah pelaksanaan, serta pembuatan perangkat pembelajaran. Banyak guru IPA SMP 
Muhammadiyah Kabupaten Sleman yang mengalami kendala dalam melaksanakan pembelajaran yang berbasiskan pada keterampilan proses sains. Pelatihan ini dilakukan untuk membekali guru IPA SMP Muhammadiyah Kabupaten Sleman bagian timur untuk dengan pemahaman tentang pengambangan perangkat pembelajaran berbasis keterampilan proses sains.

\section{Tujuan}

\section{Tujuan Umum}

Memberikan pelatihan pengembangan perangkat pembelajaran Fisika berbasis keterampilan proses.

\section{Tujuan khusus}

a. Memberikan pengetahuan dan pengalaman bagi guru IPA Fisika SMP dalam mengembangkan perangkat pembelajaran Fisika berbasis keterampilan proses.

b. Memberikan pendampingan pengembangan perangkat pembelajaran Fisika berbasis keterampilan proses.

\section{B. TINJAUAN PUSTAKA}

\section{Pembelajaran IPA Fisika}

Fisika di jenjang SMP termasuk dlaam kategori mata pelajaran IPA. Dalam dokumen kurikulum 2013, disebutkan bahwa pelajaran integrative science, bukan sebagai pendidikan disiplin ilmu. Pelajaran tersebut sebagai pendidikan berorientasi aplikatif, pengembangan kemampuan berpikir, kemampuan belajar, rasa ingin tahu, dan pengembangan sikap peduli dan bertanggung jawab terhadap lingkungan sosial dan alam. Ilmu Pengetahuan Alam juga ditujukan untuk pengenalan lingkungan biologi dan alam sekitarnya, serta pengenalan berbagai keunggulan wilayah nusantara.

Beban belajar di SMP/MTs untuk kelas VII, VIII, dan IX masing-masing 38 jam per minggu. Jam belajar SMP/MTs adalah 40 menit. Dalam struktur kurikulum SMP/MTs ada penambahan jam belajar per minggu dari semula 32, 32, dan 32 menjadi 38, 38 dan 38 untuk masing-masing kelas VII, VIII, dan IX. Sedangkan lama belajar untuk setiap jam belajar di SMP/MTs tetap yaitu 40 menit. Dengan adanya tambahan jam belajar ini dan pengurangan jumlah Kompetensi Dasar, guru memiliki keleluasaan waktu untuk mengembangkan proses pembelajaran yang berorientasi siswa aktif belajar. Proses pembelajaran siswa aktif memerlukan waktu yang lebih panjang dari proses pembelajaran penyampaian informasi karena peserta didik perlu latihan untuk melakukan pengamatan, menanya, asosiasi, menyaji, dan komunikasi. Proses pembelajaran yang dikembangkan guru menghendaki kesabaran dalam menunggu respon peserta didik karena mereka belum terbiasa.Selain itu, bertambahnya jam belajar memungkinkan guru melakukan penilaian proses dan hasil belajar.

IPA didefinisikan sebagai pengetahuan yang diperoleh melalui pengumpulan data dengan eksperimen, pengamatan, dan deduksi untuk menghasilkan suatu penjelasan tentang sebuah gejala yang dapat dipercaya. Carin dan Sund (1993) dalam PuskurDepdiknas (2006) mendefinisikan IPA sebagai “pengetahuan yang sistematis dan tersusun 
secara teratur, berlaku umum (universal), dan berupa kumpulan data hasil observasi dan eksperimen".

Merujuk pada pengertian IPA itu, pada hakikatnya IPA meliputi empat unsur utama yaitu: sikap, proses, produk, dan aplikasi. Tujuan pembelajaran IPA adalah siswa memiliki tiga kemampuan dasar IPA, yaitu: (1) kemampuan untuk mengetahui apa yang diamati, (2) kemampuan untuk memprediksi apa yang belum terjadi, dan kemampuan untuk menguji tindak lanjut hasil eksperimen, (3) dikembangkannya sikap ilmiah.

Pendidikan IPA di sekolah diharapkan dapat menjadi wahana bagi peserta didik untuk mempelajari diri sendiri dan alam sekitarnya, serta prospek pengembangan lebih lanjut dalam menerapkannya dalam kehidupan sehari-hari, yang didasarkan pada metode ilmiah. Pembelajaran IPA menekankan pada pengalaman langsung untuk mengembangkan kompetensi agar peserta didik mampu memahami alam sekitar melalui proses "mencari tahu" dan "berbuat", hal ini akan membantu peserta didik untuk memperoleh pemahaman yang lebih mendalam. Keterampilan dalam mencari tahu atau berbuat tersebut dinamakan dengan keterampilan proses penyelidikan atau "enquiry skills" yang meliputi mengamati, mengukur, menggolongkan, mengajukan pertanyaan, menyusun hipotesis, merencanakan eksperimen untuk menjawab pertanyaan, mengklasifikasikan, mengolah, dan menganalisis data, menerapkan ide pada situasi baru, menggunakan peralatan sederhana serta mengkomunikasikan informasi dalam berbagai cara, yaitu dengan gambar, lisan, tulisan, dan sebagainya. Melalui keterampilan proses dikembangkan sikap dan nilai yang meliputi rasa ingin tahu, jujur, sabar, terbuka, tidak percaya tahyul, kritis, tekun, ulet, cermat, disiplin, peduli terhadap lingkungan, memperhatikan keselamatan kerja, dan bekerja sama dengan orang lain.

Oleh karena itu pembelajaran IPA di sekolah sebaiknya: (1) memberikan pengalaman pada siswa sehingga mereka kompeten melakukan pengukuran berbagai besaran fisis, (2) menanamkan pada siswa pentingnya pengamatan empiris dalam menguji suatu pernyataan ilmiah (hipotesis). Hipotesis ini dapat berasal dari pengamatan terhadap kejadian sehari-hari yang memerlukan pembuktian secara ilmiah, (3) latihan berpikir kuantitatif yang mendukung kegiatan belajar matematika, yaitu sebagai penerapan matematika pada masalah-masalah nyata yang berkaitan dengan peristiwa alam, (4) memperkenalkan dunia teknologi melalui kegiatan kreatif dalam kegiatan perancangan dan pembuatan alat-alat sederhana maupun penjelasan berbagai gejala dan keampuhan IPA dalam menjawab berbagai masalah.

Namun pembelajaran sains yang selama ini terjadi di sekolah belum mengembangkan kecakapan berfikir siswa untuk menyelesaikan masalah yang dihadapinya. Padahal pengajaran sains dalam Kurikulum Tingkat Satuan Pendidikan (KTSP) adalah pengajaran yang mengajarkan siswa bagaimana belajar, bagaimana mengingat, bagaimana berfikir, dan bagaimana memotivasi diri mereka. Pengajaran sains merupakan proses aktif yang berlandaskan konsep konstruktivisme yang berarti bahwa sifat pengajaran sains adalah pengajaran yang berpusat pada siswa (student centered instruction). 


\section{Perangkat Pembelajaran}

Chodijah, Fauzi \& Wulan (2012: 10) menyatakan bahwa perangkat pembelajaran merupakan segala alat dan bahan yang digunakan guru untuk melakukan proses pembelajaran. Perangkat pembelajaran Fisika perlu dikembangkan sesuai dengan standar yang berlaku agar memperoleh hasil yang optimal.

Perangkat pembelajaran merupukan hal yang harus disiapkan oleh guru sebelum melaksanakan pembelajaran. Dalam KBBI (2007: 17), perangkat adalah alat atau perlengkapan, sedangkan pembelajaran adalah proses atau cara menjadikan orang belajar. Menurut Zuhdan, dkk (2011: 16) perangkat pembelajaran adalah alat atau perlengkapan untuk melaksanakan proses yang memungkinkan pendidik dan peserta didik melakukan kegiatan pembelajaran. Perangkat pembelajaran menjadi pegangan bagi guru dalam melaksanakan pembelajaran baik di kelas, laboratorium atau di luar kelas. Dalam Permendikbud No. 65 Tahun 2013 tentang Standar Proses Pendidikan Dasar dan Menengah disebutkan bahwa penyusunan perangkat pembelajaran merupakan bagian dari perencanaan pembelajaran. Perencanaan pembelajaran dirancang dalam bentuk silabus dan RPP yang mengacu pada standar isi. Selain itu, dalam perencanaan pembelajaran juga dilakukan penyiapan media dan sumber belajar, perangkat penilaian, dan skenario pembelajaran.

a. Silabus

Peraturan Menteri Pendidikan dan Kebudayaan Republik Indonesia No. 65 Tahun 2013 Tentang Standar Proses Pendidikan Dasar dan Menengah menjelaskan bahwa silabus merupakan acuan penyusunan kerangka pembelajaran untuk setiap bahan kajian mata pelajaran. Silabus dikembangkan berdasarkan Standar Kompetensi Lulusan dan Standar Isi untuk satuan pendidikan dasar dan menegah sesuai dengan pola pembelajaran pada setiap tahun ajaran tertentu. Silabus digunakan sebagai acuan dalam pengembangan rencana pelaksanaan pembelajaran.

b. RPP

Menurut Permendikbud No. 81A Tahun 2013 tentang Implementasi Kurikulum Pedoman Umum Pembelajaran, bahwa tahap pertama dalam pembelajaran menurut standar proses yaitu perencanaan pembelajaran yang diwujudkan dengan kegiatan penyusunan Rencana Pelaksanaan Pembelajaran (RPP). Selanjutnya dijelaskan bahwa RPP adalah rencana pembelajaran yang dikembangkan secara rinci dari suatu materi pokok atau tema tertentu yang mengacu pada silabus. RPP mencakup beberapa hal yaitu: (1) Data sekolah, mata pelajaran, dan kelas/ semester; (2) Materi Pokok; (3) Alokasi waktu; (4) Tujuan pembelajaran, KD dan indikator pencapaian kompetensi; (5) Materi pembelajaran; metode pembelajaran; (6) Media, alat dan sumber belajar; (7) Langkah-langkah kegiatan pembelajaran; dan (7) Penilaian.

c. Lembar Kegiatan Siswa (LKS)

Menurut Depdiknas (2007), LKS adalah lembaran yang berisi tugas yang harus dikerjakan oleh siswa. Tugas yang diperintahkan dalam LKS harus mengacu pada kompetensi dasar yang akan dicapai siswa. Tugas tersebut dapat berupa tugas teoritis dan tugas praktis (Abdul Majid, 2008: 176-177). LKS digunakan sebagai sarana untuk mengoptimalkan hasil belajar peserta didik dan meningkatkan keterlibatan peserta didik dalam proses belajar-mengajar. 
Diterbitkan oleh Lembaga Pengabdian kepada Masyarakat

Universitas Ahmad Dahlan Yogyakarta

\section{d. Instrumen Penilaian}

Penilaian bertujuan untuk mengumpulkan informasi tentang kemajuan belajar peserta didik. Dalam Permendikbud No. 81A Tahun 2013 tentang Implementasi Kurikulum Pedoman Umum Pembelajaran dijelaskan bahwa penilaian dalam setiap mata pelajaran meliputi kompetnsi pengetahuan, kompetensi keterampilan dan kompetensi sikap. Penilaian dilakukan berdasarkan indikator-indikator pencapaian hasil belajar dari masingmasing domain tersebut. Ada beberapa teknik dan instrumen penilaian yang digunakan untuk mengumpulkan informasi tentang kemajuan peserta didik baik berupa tes maupun non-tes antara lain tes tertulis, penilaian unjuk kerja, penilaian sikap, penilaian hasil karya, penilaian portofolio dan penilaian diri.

\section{Keterampilan Proses Sains}

Keterampilan merupakan kemampuan menggunakan pikiran, nalar, dan perbuatan secara efisien dan efektif untuk mencapai suatu hasil tertentu, termasuk kreativitas. Proses didefinisikan sebagai perangkat keterampilan kompleks yang digunakan ilmuwan dalam melakukan penelitian ilmiah. Proses merupakan konsep besar yang dapat diuraikan menjadi komponen-komponen yang harus dikuasai seseorang bila akan melakukan penelitian.

Menurut Rustaman (2003), keterampilan proses adalah keterampilan yang melibatkan keterampilan-keterampilan kognitif atau intelektual, manual dan sosial. Keterampilan kognitif terlibat karena dengan melakukan keterampilan proses siswa menggunakan pikirannya. Keterampilan manual jelas terlibat dalam keterampilan proses karena mereka melibatkan penggunaan alat dan bahan, pengukuran, penyusunan atau perakitan alat. Keterampilan sosial juga terlibat dalam keterampilan proses karena mereka berinteraksi dengan sesamanya dalam melaksanakan kegiatan belajar-mengajar, misalnya mendiskusikan hasil pengamatan. Keterampilan proses perlu dikembangkan melalui pengalaman-pengalaman langsung sebagai pengalaman belajar. Melalui pengalaman langsung, seseorang dapat labih menghayati proses atau kegiatan yang sedang dilakukan.

Keterampilan proses sains (KPS) adalah perangkat kemampuan kompleks yang biasa digunakan oleh para ilmuwan dalam melakukan penyelidikan ilmiah ke dalam rangkaian proses pembelajaran. Menurut Dahar (1996), keterampilan proses sains (KPS) adalah kemampuan siswa untuk menerapkan metode ilmiah dalam memahami, mengembangkan dan menemukan ilmu pengetahuan. KPS sangat penting bagi setiap siswa sebagai bekal untuk menggunakan metode ilmiah dalam mengembangkan sains serta diharapkan memperoleh pengetahuan baru atau mengembangkan pengetahuan yang telah dimiliki.

KPS terdiri dari sejumlah keterampilan tertentu. Klasifikasi KPS adalah sebagai berikut:

\section{Mengamati}

Mengamati adalah proses pengumpulan data tentang fenomena atau peristiwa dengan menggunakan inderanya. Untuk dapat menguasai keterampilan mengamati, siswa harus menggunakan sebanyak mungkin inderanya, yakni melihat, mendengar, merasakan, mencium dan mencicipi. Dengan demikian dapat mengumpulkan fakta-fakta yang relevan dan memadai.

2. Mengelompokkan/Klasifikasi 
Mengelompokkan adalah suatu sistematika yang digunakan untuk menggolongkan sesuatu berdasarkan syarat-syarat tertentu. Proses mengklasifikasikan tercakup beberapa kegiatan seperti mencari kesamaan, mencari perbedaan, mengontraskan ciri-ciri, membandingkan, dan mencari dasar penggolongan.

\section{Menafsirkan}

Menafsirkan hasil pengamatan ialah menarik kesimpulan tentatif dari data yang dicatatnya. Hasil-hasil pengamatan tidak akan berguna bila tidak ditafsirkan. Karena itu, dari mengamati langsung, lalu mencatat setiap pengamatan secara terpisah, kemudian menghubung-hubungkan hasil-hasil pengamatan itu. Selanjutnya siswa mencoba menemukan pola dalam suatu seri pegamatan, dan akhirnya membuat kesimpulan.

\section{Meramalkan}

Meramalkan adalah memperkirakan berdasarkan pada data hasil pengamatan yang reliabel (Firman, 2000). Apabila siswa dapat menggunakan pola-pola hasil pengamatannya untuk mengemukakan apa yang mungkin terjadi pada keadaan yang belum diamatinya, maka siswa tersebut telah mempunyai kemampuan proses meramalkan.

\section{Mengajukan pertanyaan}

Keterampilan proses mengajukan pertanyaan dapat diperoleh siswa dengan mengajukan pertanyaan apa, mengapa, bagaimana, pertanyaan untuk meminta penjelasan atau pertanyaan yang berlatar belakang hipotesis.

6. Merumusakan hipotesis

Hipotesis adalah suatu perkiraan yang beralasan untuk menerangkan suatu kejadian atau pengamatan tertentu.

7. Merencanakan percobaan

Agar siswa dapat memiliki keterampilan merencanakan percobaan maka siswa tersebut harus dapat menentukan alat dan bahan yang akan digunakan dalam percobaan. Selanjutnya, siswa harus dapat menentukan variabel-variabel, menentukan variabel yang harus dibuat tetap, dan variabel mana yang berubah. Demikian pula siswa perlu untuk menentukan apa yang akan diamati, diukur, atau ditulis, menentukan cara dan langkahlangkah kerja. Selanjutnya siswa dapat pula menentukan bagaimana mengolah hasil-hasil pengamatan.

8. Menggunakan alat dan bahan

Untuk dapat memiliki keterampilan menggunakan alat dan bahan, dengan sendirinya siswa harus menggunakan secara langsung alat dan bahan agar dapat memperoleh pengalaman langsung. Selain itu, siswa harus mengetahui mengapa dan bagaimana cara menggunakan alat dan bahan.

\section{Menerapkan konsep}

Keterampilan menerapkan konsep dikuasai siswa apabila siswa dapat menggunakan konsep yang telah dipelajarinya dalam situasi baru atau menerapkan konsep itu pada pengalaman-pengalaman baru untuk menjelaskan apa yang sedang terjadi.

10. Berkomunikasi

Keterampilan ini meliputi keterampilan membaca grafik, tabel, atau diagram dari hasil percobaan. Menggambarkan data empiris dengan grafik, tabel, atau diagram juga termasuk berkomunikasi. Menurut Firman (2000), keterampilan berkomunikasi adalah keterampilan menyampaikan gagasan atau hasil penemuannya kepada orang lain. 
Diterbitkan oleh Lembaga Pengabdian kepada Masyarakat

Universitas Ahmad Dahlan Yogyakarta

\section{METODE}

Kegiatan pengabdian ini dilakukan melalui tiga tahapan. Tahapan perencanaan, tahap pelaksanaan, dan tahap evaluasi.

Tahap perencanaan dilakukan melalui koordinasi dengan pada Dikdasmen PDM Depok. Selanjutnya melakukan hubungan kerjasama atau kesepakatan pelatihan dengan pihak-pihak terkait yaitu guru IPA di area kabupaten Sleman bagian Timur sebagai peserta pelatihan dan kepala sekolah di SMP Muhammadiyah 2 Depok Sleman sebagai penyedia tempat. Hasil koordinasi kemudian dijadikan sebagai bahan masukan di dalam pelaksanaan pelatihan.

Pada tahap perencvanaan juga dibahas mengenai guru calon peserta kegiatan pelatihan yang berasal dari 9 sekolah. Guru calon peserta pelatihan yaitu guru IPA SMP MUH 1 depok (3 orang), guru IPA SMP Muh 2 depok (2 orang), guru IPA SMP Muh 3 depok ( 2 orang), guru IPA SMP Muh 1 Prambanan ( 2 Orang), guru IPA SMP Muh 2 Prambanan ( 2 orang), guru IPA MTs MBS Prambanan (2 orang), guru IPA SMP Muh 1 Berbah ( 2 orang), guru IPA SMP Muh 1 Kalasan (2 orang), dan guru IPA SMP Muh 2 Kalasan (2 orang).

Tahap terakhir adalah evaluasi. Tahap ini ditujukan untuk mengetahui respon peserta atas pelatihan yang diselenggarakan. Respon diketahui melalui respon yang diberikan peserta pada angket yang dibagikan kepada peserta.

\section{HASIL, PEMBAHASAN DAN DAMPAK}

Tahap pelaksanaan merupakan tahap pelatihan pengembangan perangkat pembelajaran dan pendampingan guru di dalam mengembangkan perangkat pembelajaran. Pelaksanaan pelatihan dilakukan melalui dua sesi. Sesi pertama dihadiri oleh 12 guru dan sesi kedua dihadiri oleh 12 guru.

Pemateri pada sesi pertama adalah Dr. Widodo. Materi-materi pada sesi pertama berupa materi pengenalan keterampilan proses sains, ciri-ciri keterampilan proses sains tingkat dasar dan terpadu, perancangan perangkat-perangkat pembelajaran yang sesuai dengan prinsip keterampilan proses sains, serta contoh perangkat pembelajaran yang sesuai dengan prinsip keterampilan proses sains. Pada sesi ini dibagikan buku keterampilan proses sains karangan Cony Setiawan, dkk.

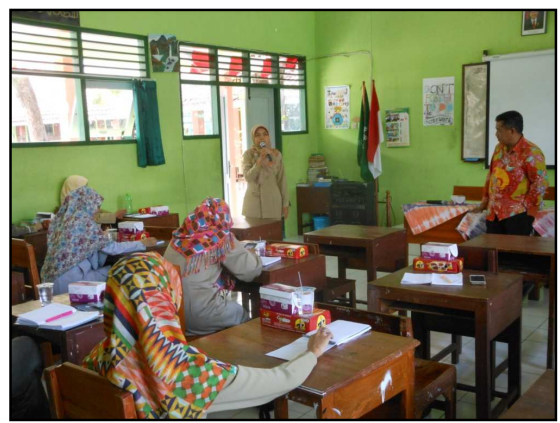

Gambar 9.1. Bapak Dr. Widodo melakukan apersepsi tentang pelaksanaan keterampilan proses di sekolah 


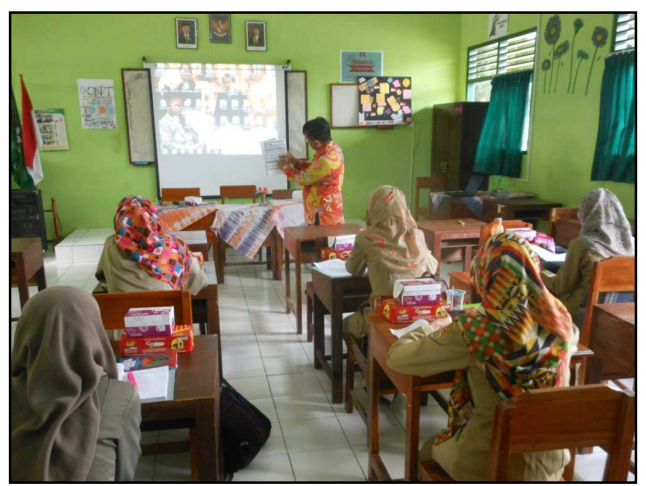

Gambar 9.2. Bapak Dr. Widodo memberikan materi dan menjelaskan contoh perangkat keterampialan proses sains

Sesi kedua pada pelatihan berupa praktik eksperimen pada tahapan keterampilan proses sains. Materi yang diangkat adalah rangkaian listrik paralel dan seri. Dengan menggunakan kit ipa yang tersedia di sekolah, para peserta diminta untuk merancang langkah-langkah percobaan untuk diajarkan pada siswa di sekolah terkait materi ramgkaian listrik paralel dan seri.

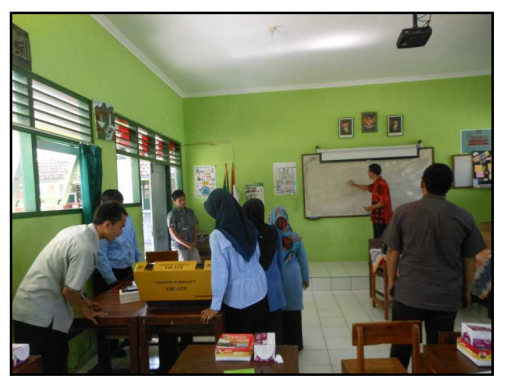

Gambar 9.3. Bapak Eko Nursulistiyo, M.Pd memberikan arahan penyusunan langkah kerja eksperimen materi rangakaian listrik

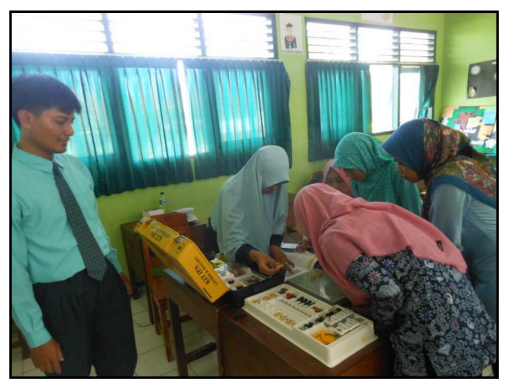

Gambar 9.4. Guru menyusun langkah kerja eksperimen materi rangakaian listrik

Pelaksanaan kegiatan pengabdian masyarakat ini melibartkan mahasiswa. Terdapat empat mahasiswa yang terlibat dalam pengabdian, yaitu Ihya, Jumaidin, Endra, serta Yoga. Ihya dan Juma membantu dalam hal teknis pelaksanaan kegiatan. Endra dan Yoga terlibat dalam membantu mengarahkan guru menyusun langkah kerja eksperimen rangkaian listrik. 
Diterbitkan oleh Lembaga Pengabdian kepada Masyarakat

Universitas Ahmad Dahlan Yogyakarta

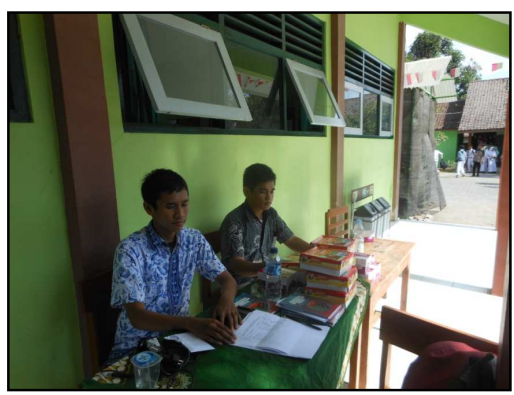

Gambar 9.5. Mahasiswa membantu pelaksanaan teknis pengabdian

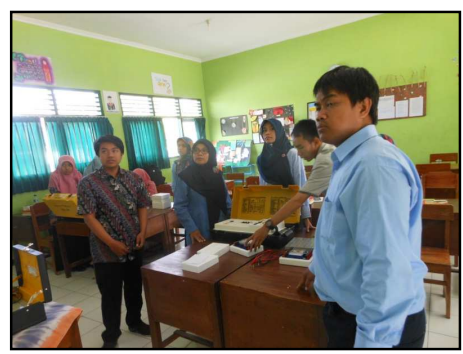

Gambar 9.6. Mahasiswa membantu mengarahkan guru menyusun langkah kerja eksperimen rangkaian listrik

\section{E. PENUTUP}

1. Kesimpulan

Kegiatan pelatihan pengembangan perangkat pembelajaran fisika berbasis keterampilan proses di SMP Muhammadiyah 2 Depok Sleman Alhamdulillah dapat berjalan lancar.

2. Saran

Perlu untuk dilakukan kegiatan serupa terutama untuk eksperimen terkait kit IPA lainnya.

\section{DAFTAR PUSTAKA}

Chodijah, S., Fauzi, A., \& Wulan, R. 2012. "Pengembangan Perangkat Pembelajaran Fisika Menggunakan Model Guided Inquiry yang Dilengkapi Penilaian Portofolio pada Materi Gerak Melingkar”. Jurnal Penelitian Pembelajaran Fisika, (I), 1-19.

Majid, Abdul. 2008. Perencanaan Pembelajaran. Bandung: PT Remaja Rosdakarya

Mulyasa, E. 2008. Menjadi Guru Profesional Menciptakan Pembelajaran Kreatif dan Menyenangkan. Bandung: Remaja Rosdakarya.

Kusumaningrum, Sih. 2015. Pengembangan Perangkat Pembelajaran Berbasis Pendekatan Saintifik dengan Model Pembelajaran PjBL untuk Meningkatkan Keterampilan Proses Sains dan Kreativitas Siswa Kelas X. Tesis. Pascasarja UNY

Zuhdan Kun Prasetyo, dkk. 2011. Pengembangan Perangkat Pembelajaran Sains Terpadu Untuk Meningkatkan Kognitif, Keterampilan Proses, Kreativitas serta Menerapkan Konsep Ilmiah Peserta Didik SMP. Program Pascasarjana UNY. 
